\title{
DIGITAL CITIZENSHIP IN HIGHER EDUCATION STUDENTS
}

\author{
Zoroayka V. Sandoval, Middle Georgia State University, vicky.sandoval@gmail.com
}

\begin{abstract}
As technology has advanced, participation in the online society is common among technology users. It is very common that people use smartphones, tablets, digital watches, and computers for work, study, and personal purposes. However, researchers have recommended that students must be taught digital citizenship practices and skills since their early education. This quantitative study determined whether there were statistically significant differences between higher education students' perception of digital citizenship and their age, gender, amount of time spent online, and computational skills. Based on the results, there were significant differences found and some recommendations for faculty to reinforce digital citizenship practices in higher education students are presented.
\end{abstract}

Keywords: Digital Citizenship, Digital Society, Digital Literacy, Higher Education

\section{INTRODUCTION}

As the use of technological digital tools on a daily basis is increasing, digital citizenship needs to be considered, understood, and applied by technology users. Several researchers define digital citizenship as the norms, behavior, and ethical choices with regards of the use of technology (Kara, 2018; Ribble, 2012; Ribble, 2004; Kim \& Choi, 2018).

Students at all levels are using different devices, such as smartphones, laptops, or desktops, to find information for educational and personal purposes, to socialize, post on blogs or discussions, and to buy goods from online sellers, just to mention some. Either at home or at school, students have access to the Internet. At school, they are usually required to browse the Internet and look for information or collaborate and communicate with peers. Thus, the use of Internet and online tools for educational purposes, either in face-to-face or online courses, has increased over the years.

Higher education students usually submit assignments online and collaborate with others through online dialogues or social media. Therefore, as Kara (2018) arguments, "there is a need for safety on the Internet because the Internet and social media are not secure" (p. 182). As stated by Nordin et. al. (2016), there is a "rising concern among educators as digital technology and the Internet prevade every aspect of students' lives" (p. 71). Risks associated with the use of technology that have been identified are violence, racism, information security and identity theft, cyberbullying, and sexting, among others. Thus, student safety, privacy, and health and well-being must be protected (Gleason \& von Guillern, 2018; Al-Zahrani, 2015) in order to prevent the previously mentioned risks. Some techniques, such as the use of social media and activities for hybrid education, have been used to promote and reinforce digital citizenship among learners (Pedersen, Norgaard, \& Koppe, 2018; Gleason \& von Guillern, 2018).

Recently, Gleason and von Gillern (2018) identified a need for the integration of digital citizenship education in the curriculum of every student in order to "emphasize the real-life experience, values, and personal interests and engagements of young people themselves" (p. 200). Research has been conducted in terms of digital citizenship for K-12 population, focusing on the integration and evaluation of these practices (Kim \& Choi, 2018; Gleason \& von Gillern, 2018; Blevins, LeCompte, \& Wells, 2016; Truong-White \& McLean, 2015; Hollandsworth, Donovan, \& Welch, 2017), and in higher education levels (Isman \& CananGungoren, 2014; Elcicek, Erdemci, \& Karal, 2018; Kara, 2018; Nordin et. al., 2016). Ribble and Bailey (2004) have identified nine categories in which administrators and technology leaders can focus to provide students digital citizenship education. These areas are (1) etiquette, (2) 
communication, (3) education, (4) access, (5) commerce, (6) responsibility, (7) rights, (8) safety, and (9) security. Ribble (2014) also identified three main themes for digital citizenship: (1) respect, (2) educate, and (3) protect.

In his S3 (Safe, Savvy, and Social) framework, Ribble (2014) defines the three main themes as:

- Respect Yourself/Respect Others: this is the social element of the framework and is defined as "respecting yourself as a digital citizen [creating cooperative and interdependent relationships and understanding of others] (para. 13)".

- Educate Yourself/Connect with Others: this is the savvy element of the framework and is defined as "creating educated digital citizens [wisdom and practical knowledge; the understanding to make good judgments] (para. 12)".

- Protect Yourself/Protect Others: this is the safety element of the framework and is defined as "protecting digital citizens [being protected from or unlikely to cause danger, risk, or injury to yourself or to others] (para. 11)".

Several researchers have used a combination of these areas as a framework to create instruments and measure students' digital citizenship practices (Isman \& CananGungoren, 2014; Nordin et. al., 2016).

Educators at all levels must be prepared to be role models and promote best practices and education in the use of the Internet and technology. According to Curran and Ribble (2017), students of all ages must be prepared to "lead with empathy and respect, to create solutions and be problem solvers, and value the participatory nature of digital citizenship" (p. 36).

For young students, it is imperative that educators include in the curriculum activities to teach them how to be responsible digital citizens. In higher education, students' digital citizenship practices can be analyzed in order to determine the areas in which they need reinforcement. In his instrument, Al-Zahrani (2015) addresses topics such as online rights and responsibilities, digital practices, electronic commerce, and technology safety to measure individuals' digital citizenship practices. It is important to know how students behave online and if they are aware of the risks associated with the use of technological tools, even if they are used for educational purposes.

In this study, the researcher analyzed digital citizenship practices among higher education students in terms of respect, education, and protection.

\section{PURPOSE OF THE STUDY}

The aim of this study was to determine whether there were significant differences between the four independent variables of (1) age, (2) gender, (3) amount of time spent online on a typical day, and (4) computational skills and the three dependent variables of the Digital Citizenship Scale (1) respect yourself/respect others, (2) educate yourself/connect with others, and (3) protect yourself/protect others. Consistent with the purpose of this study, four research questions were stated:

RQ1: Are there significant mean differences between the independent variable of age and each of the three dependent variables of the Digital Citizenship Scale (respect yourself/respect others, educate yourself/connect with others, and protect yourself/protect others) separately?

RQ2: Are there significant mean differences between the independent variable of gender and each of the three dependent variables of the Digital Citizenship Scale (respect yourself/respect others, educate yourself/connect with others, and protect yourself/protect others) separately? 
RQ3: Are there significant mean differences between the independent variable of the amount of time spent online on a typical day and each of the three dependent variables of the Digital Citizenship Scale (respect yourself/respect others, educate yourself/connect with others, and protect yourself/protect others) separately?

RQ4: Are there significant mean differences between the independent variable of computational skills and each of the three dependent variables of the Digital Citizenship Scale (respect yourself/respect others, educate yourself/connect with others, and protect yourself/protect others) separately?

\section{METHODOLOGY}

\section{Instrument}

A Digital Citizenship Scale developed by Al-Zahrani (2015) was used in this study. The instrument is composed of 3 subscales: (1) respect yourself/respect others, (2) educate yourself/connect with others, and (3) protect yourself/protect others with a total of 46 questions. Data was collected using a five-point Likert scale ranging from 5 - Strongly Agree and 1 - Strongly Disagree. It is reported that this instrument is valid and reliable, indicating an acceptable internal consistency level (Al-Zahrani, 2015). Also, demographic questions, such as age, gender, self-perceived computational skills, amount of time spent online on a typical day, and the main purpose of Internet use were collected.

\section{Data Collection}

After IRB approval, the link to the survey was sent via email to undergraduate Information Technology students enrolled in higher education level (all 4 years of school) at a university in the Southeast USA; the link was re-sent 10 days later for a total of a 20-day data collection period. A total of 83 responses were collected during this period. Of the 83 responses, one was removed because it was incomplete, producing a sample of 82 for the study. From the sample $(\mathrm{N}=82), 67.1 \%$ were male $(\mathrm{N}=55)$ and $32.9 \%$ were female $(\mathrm{N}=27)$. Participants' age was grouped in the following categories: $18-25(\mathrm{~N}=50 ; 61 \%), 26-30(\mathrm{~N}=11 ; 13.4 \%), 31-35(\mathrm{~N}=6 ; 7.3 \%)$, and 36 or older $(\mathrm{N}=16 ; 18.3 \%)$.

\section{Data Analysis}

In order to test the significance of groups' differences and analyze the data collected for RQ1, RQ2, RQ3, and RQ4, one-way ANOVAs were conducted. ANOVA is a method used to compare the means of the groups and determine statistically significant differences between them (Lane, $\mathrm{n}$. d.). In order to determine the significance of the groups, $\mathrm{F}$ test was used. For groups with more than 2 levels, post-hoc analysis using the Tukey HSD test was conducted. In this study, four independent variables were included: (1) age, (2) gender, (3) amount of time spent online on a typical day, and (4) computational skills. The three dependent variables were: (1) respect oneself and others, (2) educate oneself and others, and (3) protect oneself and others.

\section{Results}

Participants were asked their average time spent using the Internet on a typical day, as well as their perception of their computational skills. Table 1 shows that about equal percentage of participants spend from 3 to 8 hours online on a daily basis. Surprisingly, $26.8 \%$ of the participants spend more than 10 hours online per day. Results for their selfreported computational skills are shown in Table 2. Almost all participants considered their computational skills to be intermediate or advanced. 
Table 1. Daily Internet Use

\begin{tabular}{|l|r|r|r|}
\hline \multicolumn{1}{|c|}{ Group } & N & \multicolumn{1}{c|}{ \% } & \multicolumn{1}{c|}{$\begin{array}{c}\text { Cumulative } \\
\text { \% }\end{array}$} \\
\hline 0 to 2 hours & 3 & 3.7 & 3.7 \\
\hline 3 to 4 hours & 17 & 20.7 & 24.4 \\
\hline 5 to 6 hours & 15 & 18.3 & 42.7 \\
\hline 7 to 8 hours & 15 & 18.3 & 61 \\
\hline 9 to 10 hours & 10 & 12.2 & 73.2 \\
\hline more than 10 hours & 22 & 26.8 & 100 \\
\hline
\end{tabular}

Table 2. Computational Skills

\begin{tabular}{|l|r|r|r|}
\hline \multicolumn{1}{|c|}{ Group } & \multicolumn{1}{c|}{ N } & \multicolumn{1}{c|}{$\boldsymbol{1}$} & \multicolumn{1}{c|}{$\begin{array}{c}\text { Cumulative } \\
\text { \% }\end{array}$} \\
\hline Beginner & 3 & 3.7 & 3.7 \\
\hline Intermediate & 48 & 58.5 & 62.2 \\
\hline Advanced & 31 & 37.8 & 100 \\
\hline
\end{tabular}

Results of the descriptive analyses are shown in Table 3. Participants revealed agreement to the subscales related to respect and education. However, a more neutral position was revealed for the subscale related to protection.

Table 3. Means and Standard Deviations of the Subscales

\begin{tabular}{|l|r|r|}
\hline & \multicolumn{1}{|c|}{ Mean } & \multicolumn{1}{c|}{$\begin{array}{c}\text { Std. } \\
\text { Deviation }\end{array}$} \\
\hline Respect Yourself / Respect Others & 4.34 & 0.547 \\
\hline Educate Yourself / Connect with Others & 4.14 & 0.573 \\
\hline Protect Yourself / Protect Others & 3.72 & 0.746 \\
\hline
\end{tabular}

RQ1: Are there significant mean differences between the independent variable of age and each of the three dependent variables of the Digital Citizenship Scale (respect yourself/respect others, educate yourself/connect with others, and protect yourself/protect others) separately?

Results of the ANOVA for RQ1 revealed no significant difference between age and the digital citizenship subscales of Respect (F3,78=.846, $p=.473)$, Educate $(\mathrm{F} 3,78=1.032, p=.383)$, and Protect $(\mathrm{F} 3,78=1.018, p=.389)$. Results of ANOVA are shown in Table 4, and descriptive statistics in Table 5. 
Issues in Information Systems

Volume 20, Issue 4, pp. 93-103, 2019

Table 4. ANOVA Results for Age

\begin{tabular}{|l|l|r|r|r|r|r|}
\hline \multicolumn{2}{|c}{} & $\begin{array}{c}\text { Sum of } \\
\text { Squares }\end{array}$ & \multicolumn{1}{c|}{ df } & $\begin{array}{c}\text { Mean } \\
\text { Square }\end{array}$ & \multicolumn{1}{c|}{ F } & \multicolumn{1}{c|}{ Sig. } \\
\hline \multirow{2}{*}{ Respect } & Between Groups & 0.765 & 3 & 0.255 & 0.846 & 0.473 \\
\cline { 2 - 8 } \multicolumn{1}{|l|}{ Educate } & Within Groups & 23.515 & 78 & 0.301 & & \\
\cline { 2 - 8 } & Total & 24.28 & 81 & & & \\
\hline \multirow{2}{*}{ Protect } & Between Groups & 1.016 & 3 & 0.339 & 1.032 & 0.383 \\
\cline { 2 - 8 } & Within Groups & 25.601 & 78 & 0.328 & & \\
\cline { 2 - 8 } & Total & 26.617 & 81 & & & \\
\cline { 2 - 8 } & Between Groups & 1.7 & 3 & 0.567 & 1.018 & 0.389 \\
\cline { 2 - 8 } & Within Groups & 43.435 & 78 & 0.557 & & \\
\cline { 2 - 8 } & Total & 45.135 & 81 & & & \\
\hline
\end{tabular}

Table 5. Descriptive Statistics for Age

\begin{tabular}{|l|l|r|r|r|}
\hline \multicolumn{2}{|c}{} & \multicolumn{1}{c|}{$\mathbf{N}$} & \multicolumn{1}{c|}{ Mean } & \multicolumn{1}{c|}{$\begin{array}{c}\text { Std. } \\
\text { Deviation }\end{array}$} \\
\hline \multirow{2}{*}{ Respect } & $18-25$ & 50 & 4.283 & 0.49555 \\
\cline { 2 - 5 } & $26-30$ & 11 & 4.2866 & 0.9296 \\
\cline { 2 - 5 } & $31-35$ & 6 & 4.4829 & 0.37409 \\
\cline { 2 - 5 } & 36 or older & 15 & 4.513 & 0.39103 \\
\cline { 2 - 5 } & Total & 82 & 4.3402 & 0.5475 \\
\hline \multirow{5}{*}{ Educate } & $18-25$ & 50 & 4.2055 & 0.5046 \\
\cline { 2 - 5 } & $26-30$ & 11 & 3.9256 & 0.94809 \\
\cline { 2 - 5 } & $31-35$ & 6 & 4.2576 & 0.21831 \\
\cline { 2 - 6 } & 36 or older & 15 & 4.0206 & 0.52762 \\
\cline { 2 - 6 } & Total & 82 & 4.1379 & 0.57324 \\
\hline & $18-25$ & 50 & 3.6096 & 0.74593 \\
\cline { 2 - 6 } & $26-30$ & 11 & 3.8843 & 0.81219 \\
\cline { 2 - 6 } & $31-35$ & 6 & 4.0152 & 0.61232 \\
\cline { 2 - 6 } & 36 or older & 15 & 3.8545 & 0.74158 \\
\cline { 2 - 5 } & Total & 82 & 3.721 & 0.74647 \\
\hline
\end{tabular}




\section{Issues in Information Systems}

Volume 20, Issue 4, pp. 93-103, 2019

RQ2: Are there significant mean differences between the independent variable of gender and each of the three dependent variables of the Digital Citizenship Scale (respect yourself/respect others, educate yourself/connect with others, and protect yourself/protect others) separately?

Results of the ANOVA for RQ2 revealed a statistically significant difference between gender and the digital citizenship subscales of Respect ( $\mathrm{F} 1,80=6.937, p=.01)$, and Protect $(\mathrm{F} 1,80=7.115, p=.009)$. Female subjects were more concerned about respect and protect than male subjects. Results of ANOVA are shown in Table 6, and descriptive statistics in Table 7.

Table 6. ANOVA Results for Gender

\begin{tabular}{|l|l|r|r|r|r|r|}
\hline \multicolumn{2}{|l}{} & \multicolumn{1}{|c|}{$\begin{array}{c}\text { Sum of } \\
\text { Squares }\end{array}$} & \multicolumn{1}{c|}{ df } & \multicolumn{1}{c|}{$\begin{array}{c}\text { Mean } \\
\text { Square }\end{array}$} & F & Sig. \\
\hline \multirow{2}{*}{ Respect } & Between Groups & 1.937 & 1 & 1.937 & 6.937 & 0.01 \\
\cline { 2 - 8 } & Within Groups & 22.343 & 80 & 0.279 & & \\
\cline { 2 - 8 } & Total & 24.28 & 81 & & & \\
\hline \multirow{2}{*}{ Educate } & Between Groups & 0.002 & 1 & 0.002 & 0.005 & 0.942 \\
\cline { 2 - 8 } & Within Groups & 26.615 & 80 & 0.333 & & \\
\cline { 2 - 8 } & Total & 26.617 & 81 & & & \\
\hline & Between Groups & 3.686 & 1 & 3.686 & 7.115 & 0.009 \\
\cline { 2 - 8 } & Within Groups & 41.448 & 80 & 0.518 & & \\
\cline { 2 - 8 } & Total & 45.135 & 81 & & & \\
\hline
\end{tabular}

Table 7. Descriptive Statistics for Gender

\begin{tabular}{|l|l|r|r|r|}
\hline \multicolumn{2}{|c|}{} & \multicolumn{1}{c|}{ N } & \multicolumn{1}{c|}{ Mean } & \multicolumn{1}{c|}{$\begin{array}{c}\text { Std. } \\
\text { Deviation }\end{array}$} \\
\hline \multirow{2}{*}{ Respect } & Male & 55 & 4.2325 & 0.58042 \\
\cline { 2 - 5 } & Female & 27 & 4.5596 & 0.39956 \\
\cline { 2 - 5 } & Total & 82 & 4.3402 & 0.5475 \\
\hline \multirow{3}{*}{ Educate } & Male & 55 & 4.1412 & 0.60426 \\
\cline { 2 - 5 } & Female & 27 & 4.1313 & 0.51508 \\
\cline { 2 - 5 } & Total & 82 & 4.1379 & 0.57324 \\
\cline { 2 - 5 } & Male & 55 & 3.5724 & 0.71368 \\
\cline { 2 - 5 } & Female & 27 & 4.0236 & 0.73232 \\
\cline { 2 - 5 } & Total & 82 & 3.721 & 0.74647 \\
\hline
\end{tabular}




\section{Issues in Information Systems}

Volume 20, Issue 4, pp. 93-103, 2019

There was no statistically significant difference between gender and the digital citizenship subscale of Educate $(\mathrm{F} 1,80=.005, p=.942)$.

RQ3: Are there significant mean differences between the independent variable of the amount of time spent online on a typical day and each of the three dependent variables of the Digital Citizenship Scale (respect yourself/respect others, educate yourself/connect with others, and protect yourself/protect others) separately?

Results of the ANOVA for RQ3 revealed a statistically significant difference between the amount of time spent online on a typical day and the digital citizenship practices in terms of Respect oneself and others (F5,76=3.355, $p=.009)$. Post hoc comparisons using the Tukey HSD test indicated that the mean score of respect practices for participants who spend more than 10 hours a day online $(\mathrm{M}=4.52, \mathrm{SD}=.514)$ was significantly different than the score of respect practices for participants who spend 7 to 8 hours a day online $(\mathrm{M}=3.98$; $\mathrm{SD}=.738)$. No significant difference was found among participants from other time groups. Results of ANOVA are shown in Table 8, and descriptive statistics in Table 9.

Table 8. ANOVA Results for Amount of Time Spent Online

\begin{tabular}{|l|l|r|r|r|r|r|}
\hline \multicolumn{2}{|c|}{} & $\begin{array}{r}\text { Sum of } \\
\text { Squares }\end{array}$ & \multicolumn{1}{c|}{ df } & \multicolumn{1}{c|}{$\begin{array}{c}\text { Mean } \\
\text { Square }\end{array}$} & \multicolumn{1}{c|}{ F } & Sig. \\
\hline \multirow{2}{*}{ Respect } & Between Groups & 4.39 & 5 & 0.878 & 3.355 & 0.009 \\
\cline { 2 - 7 } & Within Groups & 19.89 & 76 & 0.262 & & \\
\cline { 2 - 8 } & Total & 24.28 & 81 & & & \\
\hline \multirow{2}{*}{ Pducate } & Between Groups & 2.871 & 5 & 0.574 & 1.838 & 0.115 \\
\cline { 2 - 8 } & Within Groups & 23.746 & 76 & 0.312 & & \\
\cline { 2 - 8 } & Total & 26.617 & 81 & & & \\
\hline & Between Groups & 3.153 & 5 & 0.631 & 1.141 & 0.346 \\
\cline { 2 - 8 } & Within Groups & 41.982 & 76 & 0.552 & & \\
\cline { 2 - 8 } & Total & 45.135 & 81 & & & \\
\hline
\end{tabular}




\section{Issues in Information Systems}

Volume 20, Issue 4, pp. 93-103, 2019

Table 9. Descriptive Statistics for Amount of Time Spent Online

\begin{tabular}{|c|c|c|c|c|}
\hline & & $\mathbf{N}$ & Mean & Std. Deviation \\
\hline \multirow[t]{7}{*}{ Respect } & $0-2$ hours & 3 & 3.6377 & 1.1045 \\
\hline & 3-4 hours & 17 & 4.4121 & 0.31393 \\
\hline & 5-6 hours & 15 & 4.4174 & 0.36108 \\
\hline & 7-8 hours & 15 & 3.984 & 0.7383 \\
\hline & 9-10 hours & 10 & 4.4565 & 0.30761 \\
\hline & more than 10 & 22 & 4.5178 & 0.51478 \\
\hline & Total & 82 & 4.3402 & 0.5475 \\
\hline \multirow[t]{7}{*}{ Educate } & $0-2$ hours & 3 & 3.5455 & 0.94475 \\
\hline & 3-4 hours & 17 & 4.139 & 0.55309 \\
\hline & 5-6 hours & 15 & 4.2182 & 0.35343 \\
\hline & 7-8 hours & 15 & 3.8848 & 0.75785 \\
\hline & 9-10 hours & 10 & 4.3818 & 0.39696 \\
\hline & more than 10 & 22 & 4.2248 & 0.52817 \\
\hline & Total & 82 & 4.1379 & 0.57324 \\
\hline \multirow[t]{7}{*}{ Protect } & $0-2$ hours & 3 & 3.6364 & 1.10221 \\
\hline & 3-4 hours & 17 & 3.6417 & 0.79803 \\
\hline & 5-6 hours & 15 & 3.8788 & 0.85326 \\
\hline & 7-8 hours & 15 & 3.4182 & 0.80348 \\
\hline & 9-10 hours & 10 & 3.6 & 0.50562 \\
\hline & more than 10 & 22 & 3.9475 & 0.61066 \\
\hline & Total & 82 & 3.721 & 0.74647 \\
\hline
\end{tabular}

There was no statistically significant difference between the amount of time spent online on a typical day and the digital citizenship practices in terms of Educate oneself and others ( $\mathrm{F} 5,76=1.838, p=.115)$ and Protect oneself and others ( $\mathrm{F} 5,76=1.141, p=.346)$.

RQ4: Are there significant mean differences between the independent variable of computational skills and each of the three dependent variables of the Digital Citizenship Scale (respect yourself/respect others, educate yourself/connect with others, and protect yourself/protect others) separately? 


\section{Issues in Information Systems}

Volume 20, Issue 4, pp. 93-103, 2019

Results of the ANOVA for RQ4 revealed no significant difference between computational skills and the digital citizenship practices in terms of respect oneself and others $(\mathrm{F} 3,78=.846, p=.473)$, educate oneself and others $(\mathrm{F} 3,78=1.032, p=.383)$, and protect oneself and others ( $\mathrm{F} 3,78=1.018, p=.389)$. Results of ANOVA are shown in Table 10, and descriptive statistics in Table 11.

Table 10. ANOVA Results for Computational Skills

\begin{tabular}{|l|l|r|r|r|r|r|}
\hline \multicolumn{2}{|c|}{} & \multicolumn{1}{c|}{\begin{tabular}{c} 
Sum of \\
\multicolumn{2}{|c}{ Squares }
\end{tabular}} & \multicolumn{1}{c|}{ df } & $\begin{array}{c}\text { Mean } \\
\text { Square }\end{array}$ & \multicolumn{1}{c|}{ F } & \multicolumn{1}{c|}{ Sig. } \\
\hline Respect & Between Groups & 1.52 & 2 & 0.76 & 2.638 & 0.078 \\
\cline { 2 - 8 } & Within Groups & 22.76 & 79 & 0.288 & & \\
\cline { 2 - 8 } & Total & 24.28 & 81 & & & \\
\hline \multirow{2}{*}{ Educate } & Between Groups & 0.305 & 2 & 0.153 & 0.458 & 0.634 \\
\cline { 2 - 8 } & Within Groups & 26.312 & 79 & 0.333 & & \\
\cline { 2 - 8 } & Total & 26.617 & 81 & & & \\
\cline { 2 - 8 } & Between Groups & 0.738 & 2 & 0.369 & 0.657 & 0.521 \\
\cline { 2 - 8 } & Within Groups & 44.396 & 79 & 0.562 & & \\
\cline { 2 - 8 } & Total & 45.135 & 81 & & & \\
\hline
\end{tabular}

Table 11. Descriptive Statistics for Computational Skills

\begin{tabular}{|c|c|c|c|c|}
\hline \multicolumn{2}{|c|}{} & N & Mean & $\begin{array}{c}\text { Std. } \\
\text { Deviation }\end{array}$ \\
\hline \multirow{5}{*}{ Respect } & Beginner & 3 & 3.913 & 0.80523 \\
\cline { 2 - 5 } & Intermediate & 48 & 4.2682 & 0.61361 \\
\cline { 2 - 5 } & Advanced & 31 & 4.493 & 0.35435 \\
\cline { 2 - 5 } & Total & 82 & 4.3402 & 0.5475 \\
\hline \multirow{5}{*}{ Educate } & Beginner & 3 & 3.9394 & 0.87355 \\
\cline { 2 - 5 } & Intermediate & 48 & 4.1068 & 0.62325 \\
\cline { 2 - 5 } & Advanced & 31 & 4.2053 & 0.46649 \\
\cline { 2 - 5 } & Total & 82 & 4.1379 & 0.57324 \\
\cline { 2 - 5 } & Beginner & 3 & 3.303 & 0.52486 \\
\cline { 2 - 5 } & Intermediate & 48 & 3.697 & 0.69471 \\
\cline { 2 - 5 } & Advanced & 31 & 3.7985 & 0.83989 \\
\cline { 2 - 5 } & Total & 82 & 3.721 & 0.74647 \\
\hline
\end{tabular}




\section{DISCUSSION}

The purpose of this study was to determine whether there were significant differences between the four independent variables of (1) age, (2) gender, (3) amount of time spent online on a typical day, and (4) computational skills and the three dependent variables of digital citizenship practices with regard to (1) respect yourself/respect others, (2) educate yourself/connect with others, and (3) protect yourself/protect others. Data collected from 82 participants were analyzed using four one-way ANOVAs.

The results indicated that there was a significant difference between gender and digital citizenship practices in terms of respecting oneself and others and protecting oneself and others. Although the male population was bigger in this study, the results indicated that female participants had stronger digital citizenship practices than male participants in terms of respect and protection.

Also, a significant difference was found between the time spent online on a typical day and the digital citizenship practices in terms of respect. The results suggested that participants who spend more than 10 hours online on a daily basis had stronger digital citizenship practices than those who spend less time online. Even if participants use their time online for work or school purposes, social media or gaming, they have had more experiences and exposure to digital practices in an online environment. They believe more in the digital rights and responsibilities that every digital citizen has.

Based on the results, the educate yourself and others construct was not statistically significant for the participants. This is an area that needs improvement because, as Atif and Chou (2018) discuss, education is the way to "prevent inappropriate postings, hacking incidents, or privacy infringements" (p. 153). Educators in higher education must develop and reinforce this competency in students in order to prevent them from attacks and to help them in the protection of their digital identity. For example, higher education students were not concerned about education in electronic commerce. They must be aware of the risks associated with sharing sensitive information online, such as credit cards numbers, social security numbers, or date of birth. Even that participants in this study were university students, there is a need to reinforce digital citizenship practices because not all of them have been exposed to reallife threats. It is recommended that faculty teaching in higher education include examples, tools, and discussions about the issues and dangers of participating actively in a digital society. This way, students will be able to share experiences and learn from each other, as well as improve their digital citizenship perceptions.

\section{REFERENCES}

Al-Zahrani, A. (2015). Toward digital citizenship: Examining factors affecting participation and involvement in the internet society among higher education students. International Education Studies, 8(12), 203-217.

Atif, Y., \& Chou, C. (2018). Guest editorial: digital citizenship: Innovations in education, practice, and pedagogy. Educational Technology \& Society, 21(1), 152-154.

Blevins, B., LeCompte, K., \& Wells, S. (2014). Citizenship education goes digital. The Journal of Social Studies Research, 38, 33-44.

Curran, M. B. F. X. \& Ribble, M. (2017). P-20 Model of digital citizenship. New Directions for Student Leadership, $153,35-46$.

Elcicek, M., Erdemci, H., \& Karal, H. (2018). Examining the relationship between the levels of digital citizenship and social presence for the graduate students having online education. Turkish Online Journal of Distance Education, 19(1), 203-214. 
Gleason, B., \& von Gillern, S. (2018). Digital Citizenship with Social Media: Participatory Practices of Teaching and Learning in Secondary Education. Educational Technology \& Society, 21(1), 200-212.

Hollandsworth, R., Donovan, J., \& Welch, M. (2017). Digital citizenship: You can’t go home again. TechTrends, $61,524-530$.

Isman, A., \& Canan Gungoren, O. (2014). Digital citizenship. The Turkish Online Journal of Education Technology, $13(1)$.

Kara, N. (2018). Understanding university students' thoughts and practices about digital citizenship: a mixed methods study. Educational Technology \& Society, 21(1), 172-185.

Kim, M. \& Choi, D. (2018). Development of youth digital citizenship scale and implication for educational settings. Educational Technology \& Society, 21(1), 155-171.

Lane, D. M. (n. d.). Analysis of variance. In D. Lane (Ed.), Introduction to statistics (pp. 515-575). Online Edition retrieved from http://onlinestatbook.com/Online_Statistics_Education.pdf

Nordin, M. S., Ahmad, T. B. T., Zubairi, A. M., Ismail, N. A. H., Rahman, A. H. A., Trayek, F. A. A., \& Ibrahim, M. B. (2016). Psychometric properties of a digital citizenship questionnaire. Canadian Center of Science and Education, 9 (3), 71-80.

Pedersen, A. Y., Nørgaard, R. T., \& Köppe, C. (2018). Patterns of inclusion: Fostering digital citizenship through hybrid education. Educational Technology \& Society, 21(1), 225-236.

Ribble (2012). Digital citizenship for educational change. Kappa Delta Pi Record, 48: 148-151.

Ribble, M. (2014). Digital Citizenship: Using Technology Appropriately. Retrieved from $\mathrm{http} / / / \mathrm{www}$. digitalcitizenship.net/nine-elements.html

Ribble, M. S., \& Bailey, G. D. (2004). Digital citizenship: focus questions for implementation. Learning \&Leading with Technology, 32(2), 12-15.

Truong-White, H., \& McLean, L. (2015). Digital storytelling for transformative global citizenship education. Canadian Journal of Education 38(2), 1-28. 